\title{
On the tensile creep behaviour of a directionally-solidified $\mathrm{Ni}_{3} \mathrm{Al}$-based alloy
}

\author{
M S GOPALA KRISHNA and M C PANDEY \\ Defence Metallurgical Research Laboratory, P. O. Kanchanbagh, Hyderabad 500258 , India
}

MS received 22 June 1992; revised 27 November 1992

\begin{abstract}
High temperature tensile creep behaviour of a directionally-solidified $\mathrm{Ni}_{3} \mathrm{Al}$-based alloy is presented. The study involved selection of nine alloy systems based on $\mathrm{Ni}_{3} \mathrm{Al}$. The alloys contained varying amounts of $\mathrm{Cr}$ and $\mathrm{Ta}$, fixed amounts of $1.5 \mathrm{at} . \% \mathrm{Hf}$ and $0.5 \mathrm{at} . \%$ $\mathrm{Zr}$ and doped with $0.2 \mathrm{at} . \%$ each of $\mathrm{C}$ and $\mathrm{B}$. The alloys were vacuum arc-melted into buttons and homogenized at $1050^{\circ} \mathrm{C}$ for $68 \mathrm{~h}$. The test pieces of the alloys were hot compression tested at $600,700,800$ and $900^{\circ} \mathrm{C}$. The yield strength data of some of the alloys were superior to conventionally cast Mar-M 200, a cast nickel-base superalloy widely used in gas turbine structurat applications. The best alloy system was chosen based on consistent performance in the hot compression studies. The alloy so chosen was directionally solidified and vacuumhomogenization-treated for $20 \mathrm{~h}$ at various selected temperatures. Optimum creep properties were observed at $1120^{\circ} \mathrm{C}, 20 \mathrm{~h}$ treatment. The minimum creep rate data of the DS alloy showed relatively higher values even at lower temperatures and stress levels as compared to Mar-M 200. Hence, the alloy is less promising in replacing nickel-based superalloys used as structural materials in gas turbine applications.
\end{abstract}

Keywords. Intermetallic compound; $\mathrm{Ni}_{3} \mathrm{Al}$; directionally solidified; homogenization treatment; minimum creep rate.

\section{Introduction}

$\mathrm{Ni}_{3} \mathrm{Al}$ is an ordered intermetallic compound with $\mathrm{L1}_{2}$ structure (fcc lattice). It remains in this ordered structure even very close to its melting point $\left(\approx 1390^{\circ} \mathrm{C}\right)$. It appears as cuboidal precipitates (sub-micron range) in many of the nickel-based superalloys and is mainly responsible for their high temperature strength. The volume fraction of $\mathrm{Ni}_{3} \mathrm{Al}$ in some of these alloys is as high as about $60 \%$. It is characterized by anomalous flow behaviour i.e. its flow stress increases with increasing temperature, peaks around $600^{\circ} \mathrm{C}$ and then decreases. This phenomenon of $\mathrm{Ni}_{3} \mathrm{Al}$ is of immense interest both from the scientific and technological points of view. It is widely debated in literature and many mechanisms proposed to account for the anomalous flow behaviour of $\mathrm{Ni}_{3} \mathrm{Al}$ (Paider et al 1984; Pope and Ezz 1984). In addition, $\mathrm{Ni}_{3} \mathrm{Al}$ has substantial solid solubility for many of the transition, refractory and rare-earth metals (Mishima et al 1986). This provides for further strengthening of $\mathrm{Ni}_{3} \mathrm{Al}$ by solid solution alloying with other metals for improved high temperature capabilities. However, early work showed that $\mathrm{Ni}_{3} \mathrm{Al}$ could not be used for elevated temperature applications because of its poor tensile ductility (Skinner and Talbot 1949). It was later discovered that addition of boron to $\mathrm{Ni}_{3} \mathrm{Al}$ in ppm level would result in dramatic ductility improvement (Aoki and Izumi 1979). The beneficial effect of boron, however, decreases with increase of aluminium content and the effect is almost lost after 25 at. $\% \mathrm{Al}$ i.e. stoichiometric-sensitive (Takasugi et al 1985). The improvement in ductility of $\mathrm{Ni}_{3} \mathrm{Al}$ through small boron additions and careful control of aluminium content have given rise to renewed interest in the high temperature mechanical properties of nickel 
aluminides. However, mostly compressive creep behaviour of the alloys has been studied and very limited published data on tensile creep behaviour are available.

In this paper, the developmental activities carried out at our Laboratory on $\mathrm{Ni}_{3} \mathrm{Al}$-based alloys are presented. The study involved selection of nine alloy systems based on $\mathrm{Ni}_{3} \mathrm{Al}$. The alloys contained varying amounts of $\mathrm{Cr}$ and $\mathrm{Ta}$, fixed amount of $1.5 \mathrm{at} . \% \mathrm{Hf}$ and $0.5 \mathrm{at} . \% \mathrm{Zr}$ and doped with $0.2 \mathrm{at} \%$ boron. The best alloy system out of the nine was chosen based on hot compression studies. The best alloy selected was directionally solidified (DS), heat-treated and tensile creep properties were evaluated. Its creep properties have been compared with DS Mar-M 200, an alloy widely used in gas turbine applications. It has been observed that the solid solution strengthened $\mathrm{Ni}_{3} \mathrm{Al}$ showed relatively inferior creep properties as compared to DS Mar-M 200 from aviation gas turbine application considerations.

\section{Basis for alloy composition selection}

Nine multicomponent systems based on $\mathrm{Ni}_{3} \mathrm{Al}$ were selected and designated as $\mathrm{PK} 1$ to PK9. The nominal chemical composition of the alloys is shown in table 1 . They contained varying amounts of $\mathrm{Cr}$ and $\mathrm{Ta}$ but fixed amount of $1.5 \mathrm{at} . \% \mathrm{Hf}, 0.5 \mathrm{at} . \%$ $\mathrm{Zr}$ and 0.2 at. $\%$ each of $\mathrm{C}$ and $\mathrm{B}$. The alloys can be classified into three groups: (i) PK1-PK3 alloys - 5at.\% Cr, (ii) PK4-PK6 alloys -8 at.\% Cr and (iii) PK7-PK9 alloys -8 at. $\% \mathrm{Cr}+2.5 \mathrm{at} . \% \mathrm{Ta}$. Each of the alloying elements was added on an individual basis to achieve one or more desired effects in $\mathrm{Ni}_{3} \mathrm{Al}$. For example, $\mathrm{Cr}$ was added to improve high temperature oxidation and hot-corrosion resistance of $\mathrm{Ni}_{3} \mathrm{Al}$. Ta was added not only as a solid solution strengthener but also to form its carbides. $\mathrm{B}$ was added only to ensure tensile ductility in $\mathrm{Ni}_{3} \mathrm{Al}$. In deciding the amount of each of the alloying elements and reducing the corresponding amounts of $\mathrm{Ni}$ and/or $\mathrm{Al}$, the solubility limit data at $1000^{\circ} \mathrm{C}$ and site preference of ternary additions in $\mathrm{Ni}_{3} \mathrm{Al}$ (Ochiai et al 1984a) were considered. In all cases, the solubility limit of the element in $\mathrm{Ni}_{3} \mathrm{Al}$ was not exceeded and the aluminium equivalent kept around 25 at. $\%$. Also, lattice parameter variation with solute concentration data for $\mathrm{Ni}_{3} \mathrm{Al}$ (Ochiai et al 1984b; Mishima et al 1985), past experience of the other investigators (Liu et al 1984) and well-established roles of alloying elements in conventional nickel-based super alloys (Sims et al 1987) were used as guidelines in arriving at these compositions. However, it is emphasized here that it is not possible

Table 1. Nominal chemical composition of button melted $\mathrm{Ni}_{3} \mathrm{Al}$-based alloys.

\begin{tabular}{|c|c|c|c|c|c|c|c|c|}
\hline \multirow{2}{*}{$\begin{array}{l}\text { Alloy } \\
\text { designation }\end{array}$} & \multicolumn{8}{|c|}{ Composition (at. $\%$ ) } \\
\hline & Al & $\mathrm{Cr}$ & $\mathrm{Ta}$ & $\mathrm{Hf}$ & $\mathrm{Zr}$ & $\mathrm{C}$ & B & $\mathrm{Ni}$ \\
\hline PK1 & $18 \cdot 0$ & $5 \cdot 0$ & - & 1.5 & 0.50 & $0 \cdot 20$ & 0.20 & Bal. \\
\hline PK2 & 19.5 & $5 \cdot 0$ & - & 1.5 & 0.50 & 0.20 & 0.20 & Bal. \\
\hline PK3 & 210 & 5.0 & - & 1.5 & 0.50 & 0.20 & 0.20 & Bal. \\
\hline PK4 & $17 \cdot 0$ & 8.0 & - & 1.5 & 0.50 & 0.20 & 0.20 & Bal. \\
\hline PK5 & $18 \cdot 0$ & $8 \cdot 0$ & - & 1.5 & 0.50 & 0.20 & $0 \cdot 20$ & Bal. \\
\hline PK6 & $19 \cdot 0$ & $8 \cdot 0$ & - & $1 \cdot 5$ & 0.50 & 0.20 & 0.20 & Bal. \\
\hline PK7 & $14 \cdot 5$ & $8 \cdot 0$ & $2 \cdot 5$ & 1.5 & 0.50 & $0 \cdot 20$ & 0.20 & Bal. \\
\hline PK8 & $15 \cdot 5$ & $8 \cdot 0$ & $2 \cdot 5$ & 1.5 & 0.50 & 0.20 & $0 \cdot 20$ & Bal. \\
\hline PK9 & 16.5 & 8.0 & 2.5 & 1.5 & 0.50 & $0 \cdot 20$ & 0.20 & Bal. \\
\hline
\end{tabular}


to predict any definite quantitative behaviour of multicomponent systems and hence the choice remains more or less empirical.

\section{Experimental}

Alloy systems based on $\mathrm{Ni}_{3} \mathrm{Al}$ as shown in table 1 were tungsten arc-melted into buttons ( $60 \mathrm{~g}$ each) on a water-cooled copper hearth under argon atmosphere using virgin metals and master alloys. The as-cast buttons were first $\mathrm{X}$-ray radiographed and found to contain micro-shrinkage and porosities. To heal the cast defects, stainless steel encapsulated buttons were subjected to hot isostatic pressing (HIP) for $2 \mathrm{~h}$ at $1150^{\circ} \mathrm{C}$ and $160 \mathrm{MPa}$ Argon gas pressure. After HIP, the buttons were found to be free from the defects on radiographic examination.

The hot isostatically pressed buttons were vacuum homogenized at $1050^{\circ} \mathrm{C}$ for $68 \mathrm{~h}$. These samples were then subjected to standard methods of chemical, optical, $\mathrm{X}$-ray and transmission electron microscope (TEM) examinations. Also, scanning electron microprobe analysis (SEPMA) studies on the type of precipitates present in the alloys were carried out. Line and area scanning techniques of SEPMA were used respectively to detect carbon and other elements in the precipitated regions of the alloys.

The homogenized samples were machined into $3 \mathrm{~mm}$ diam $\times 5 \mathrm{~mm}$ long cylindrical specimens for hot-compression tests. Hot-compression tests on the specimens were carried out at $600,700,800$ and $900^{\circ} \mathrm{C}$ using Instron 1185 universal testing machine with molybdenum disulphide as the lubricant. The specimens were deformed slightly above their compressive yield point and then the tests terminated. Based on the relative consistent performance of the alloys in the compression studies, PK8 alloy was selected for further investigations.

A $5 \mathrm{~kg}$ melt of PK8 alloy was vacuum-induction-melted and then directionally solidified in a ceramic shell mould (produced by lost wax process) into $12 \mathrm{~mm}$ diam rods. Metallographic observations on an as-DS rod and chemical analysis on a vacuum homogenized rod at $1050^{\circ} \mathrm{C}$ for $68 \mathrm{~h}$ were carried out.

Specimens with $3.5 \mathrm{~mm}$ diam and $17 \mathrm{~mm}$ gauge length were machined and used for constant load stress rupture and creep tests. Stress rupture tests on as-DS specimens were carried out at $900^{\circ} \mathrm{C}$ and vacuum homogenization heat treatment on stress rupture life was studied. Homogenization treatments of DS PK8 alloy was carried out for $20 \mathrm{~h}$ at $1000,1050,1120$ and $1200^{\circ} \mathrm{C}$. All the samples of the alloy homogenized at different temperatures were stress rupture tested at $900^{\circ} \mathrm{C}$ and $200 \mathrm{MPa}$. Subsequently, all the DS PK8 alloy specimens were homogenized at $1120^{\circ} \mathrm{C}$ for $20 \mathrm{~h}$ and creep tests carried out at 750,850 and $950^{\circ} \mathrm{C}$ and at stress levels of 550 , 400 and $200 \mathrm{MPa}$, respectively. Fractographic examinations were carried out on all the fractured creep specimens tested at various temperature and stress levels using a scanning electron microscope (SEM).

\section{Results and discussion}

\subsection{Results}

4.1a Chemical, structural and microstructural studies: In argon arc melting of the alloys chosen, no significant loss in weight $(<0.1 \mathrm{~g})$ was observed after melting the 
Table 2. Chemical composition of homogenized DS PK8 alloy.

\begin{tabular}{lccccccccc}
\hline & \multicolumn{7}{c}{ Chemical composition wt.\% (at.\%) } \\
\cline { 2 - 10 } Alloy & $\mathrm{Al}$ & $\mathrm{Cr}$ & $\mathrm{Ta}$ & $\mathrm{Hf}$ & $\mathrm{Zr}$ & $\mathrm{C}$ & $\mathrm{B}$ & $\mathrm{Ni}$ \\
\hline \multirow{2}{*}{ DS PK8 } & 7.4 & 7.3 & 8.1 & 4.4 & 0.76 & 0.03 & 0.03 & Bal. \\
& $(15.5)$ & $(8.0)$ & $(2.5)$ & $(1.5)$ & $(0.5)$ & $(0.2)$ & $(0.2)$ & \\
\hline
\end{tabular}

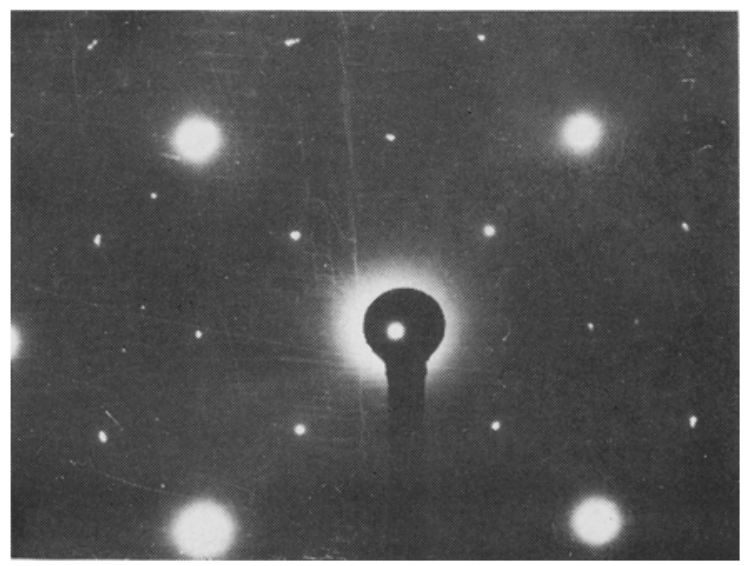

Figure 1. Electron diffraction pattern for PK8 alloy showing superlattice reflections (Zone axis: $\langle 100\rangle)$.

charges into buttons. The alloying elements were found to be well within the acceptable range of chemical composition on analysis. Similarly, on analysis as shown in table 2, the chemistry of the homogenized DS PK8 alloy was very close to its nominal chemical composition (table 1).

$\mathrm{X}$-ray diffraction study on homogenized samples of the button melted alloys showed a few lines corresponding to ordered structure of $\mathrm{Ni}_{3} \mathrm{Al}$ in diffraction patterns. However, ordered structure of the alloys was confirmed decisively by observing superlattice reflections in electron diffraction patterns obtained from TEM studies. In figure 1, electron diffraction pattern obtained for PK8 alloy is shown as an illustration.

Optical micrographs of the homogenized samples of the button melted alloys are shown in figure 2 . The microstructure showed varying amounts of $\mathrm{Ni}_{3} \mathrm{Al}\left(\tau^{\prime}\right)$ along with some precipitates and eutectic phase in the alloys. SEPMA studies of precipitates in the alloys revealed mainly chromium-rich carbides. The alloys with $\mathrm{Ta}$ additions showed (TaHfZr) rich carbides in addition to chromium carbides. Figure 3 shows these precipitates for PK8 alloy.

In figures $4 \mathrm{a}, \mathrm{b}$, the longitudinal and transverse sections of microstructure of the as-DS PK8 alloy are shown. It is clear from the micrographs that well-defined dendritic morphology was obtained on directional solidification of the alloy.

SEM studies on fractured creep tested specimens of DS PK8 alloy at all temperature and stress levels showed intergranular failure and SEM fractograph for $950^{\circ} \mathrm{C}$ at $200 \mathrm{MPa}$ crept specimen is shown in figure 5. 

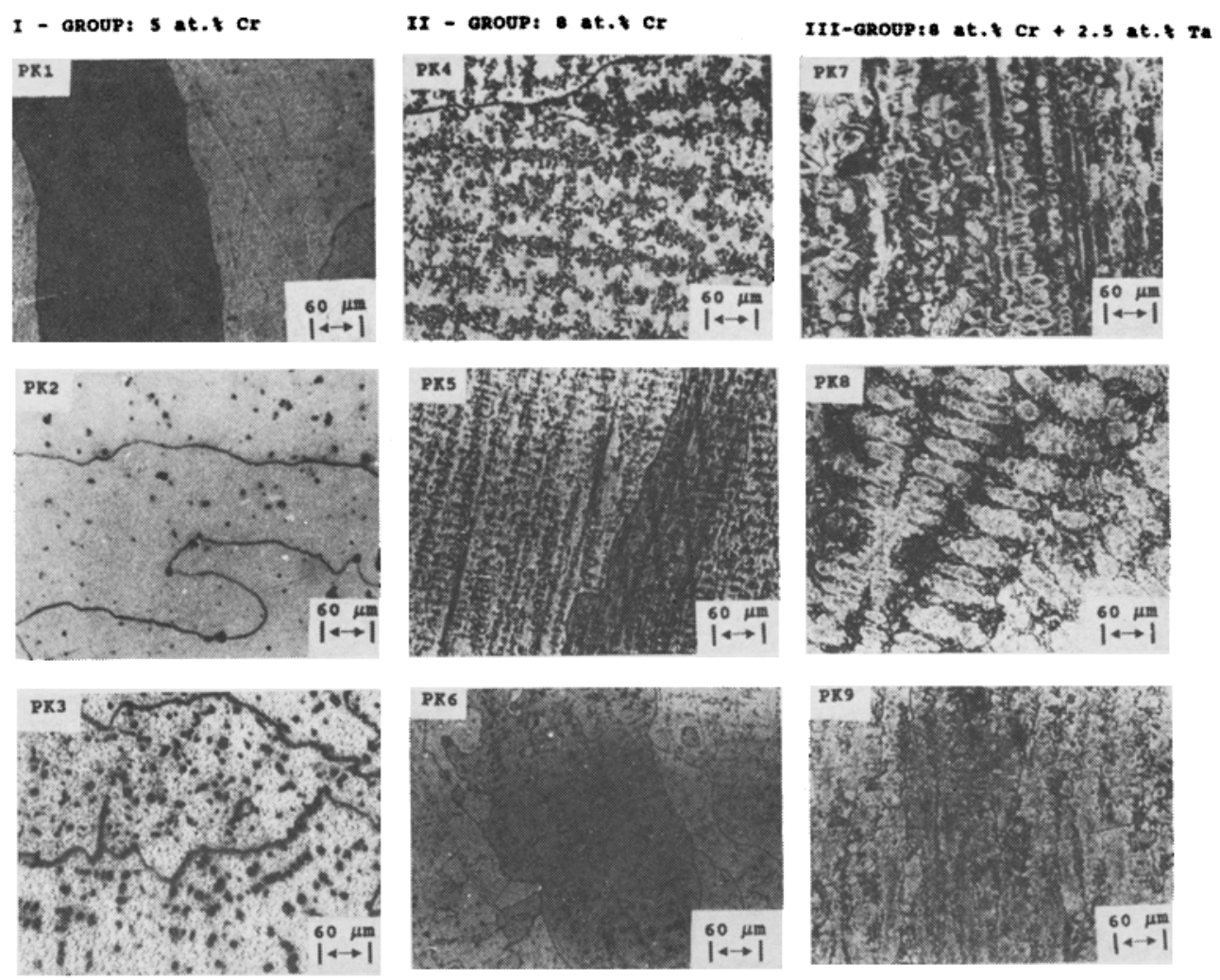

Figure 2. Microstructure of the nine-button melted $\mathrm{Ni}_{3} \mathrm{Al}$-based alloys.

4.1b Hot-compression studies: The compressive yield strength data for PK1 to PK8 alloys obtained from hot compression studies are presented in figures $6 a, b, c$. The anomalous flow behaviour observed in the case of pure $\mathrm{Ni}_{3} \mathrm{Al}$ was also observed in these alloys. Some of the alloys also showed shift in the peak flow stress value from 600 to $700^{\circ} \mathrm{C}$. Alloys with Ta addition i.e. III-group of alloys showed higher yield strength (YS) values at all the test temperatures as compared to I and II-groups of alloys, and in particular, PK8 alloy showed consistent flow behaviour at all the chosen test temperatures. Also, in figure 6c, YS data of PK7, PK8 and PK9 alloys (III-group) have been compared with conventionally cast (CC) Mar-M 200. It can be noticed that YS of PK8 alloy is superior to CC Mar-M 200.

4.2c Stress-rupture and creep studies: Stress rupture study on as-DS PK8 alloy at 900 and $950^{\circ} \mathrm{C}$ showed very low rupture life as shown in table 3 . This was attributed to microsegregation in the alloy and hence the effect of homogenization treatment on rupture life was studied. The results (table 4) indicate that the samples homogenized at $1120^{\circ} \mathrm{C}$ for $20 \mathrm{~h}$ showed significant improvement both in terms of rupture life and ductility as compared to as-DS samples. Hence, $1120^{\circ} \mathrm{C}, 20 \mathrm{~h}$ homogenization treatment was given to all the specimens of the alloy subsequently used in creep tests.

Creep curves obtained for the alloy at different temperatures and stress levels are shown in figure 7 and the creep properties are summarized in table 5 . At $750^{\circ} \mathrm{C}$ test, 

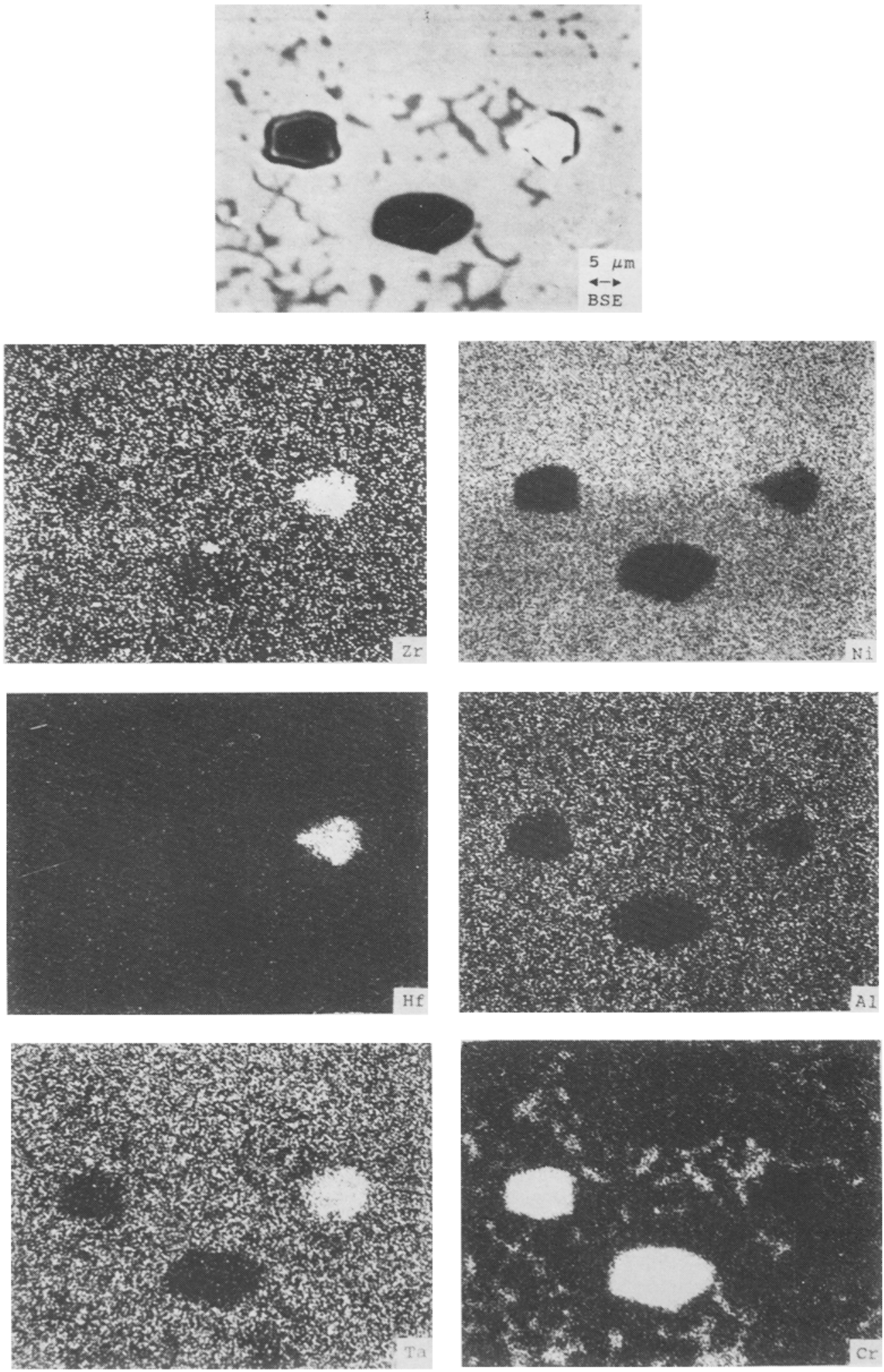

Figure 3. SEPMA of precipitates in PK8 alloy. 

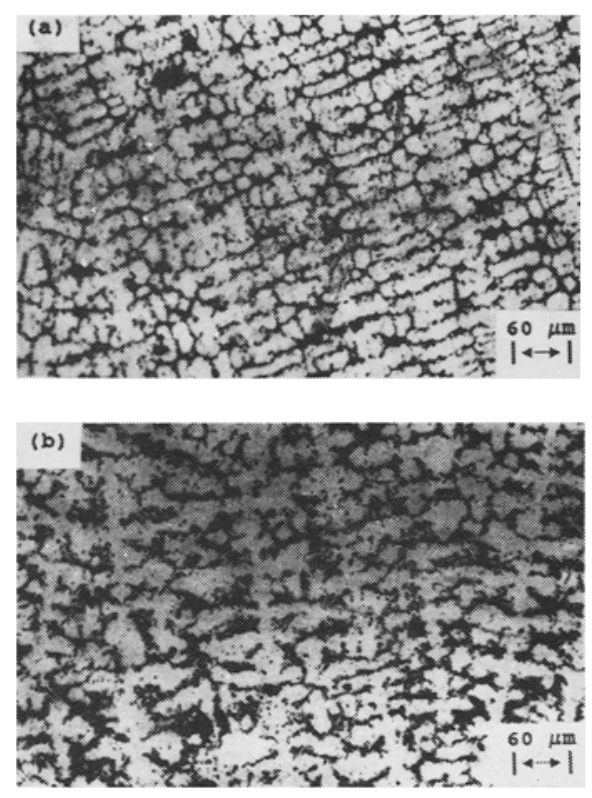

Figure 4. Microstructure of as-DS PK8 alloy. a. Longitudinal and $\mathbf{b}$. transverse sections.

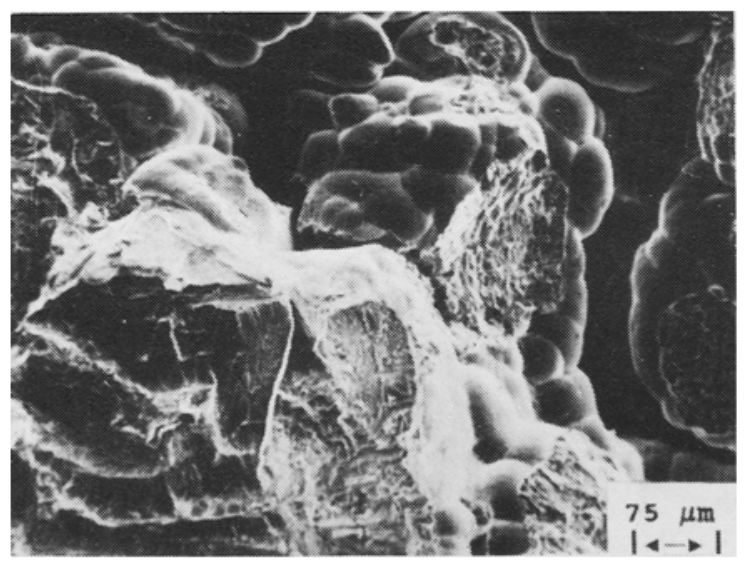

Figure 5. Fractograph of homogenized DS PK 8 alloy creep tested at $950^{\circ} \mathrm{C}$ and $200 \mathrm{MPa}$.

the alloy showed very little creep ductility. In table 6 , the minimum creep rate data of the alloy has been compared with the data obtained from the creep curves of DS Mar-M 200 by Piearcey and Terkelsen (1967). It is clear that the homogenized DS PK8 alloy has relatively higher creep rate even at lower temperatures and stress levels as compared to DS Mar-M 200.

\subsection{Discussion}

Superior resistance to plastic flow and long range order in $\mathrm{Ni}_{3} \mathrm{Al}$ would be expected to decrease diffusion-controlled creep rates. Thus, $\mathrm{Ni}_{3} \mathrm{Al}$-based alloys with ordered 

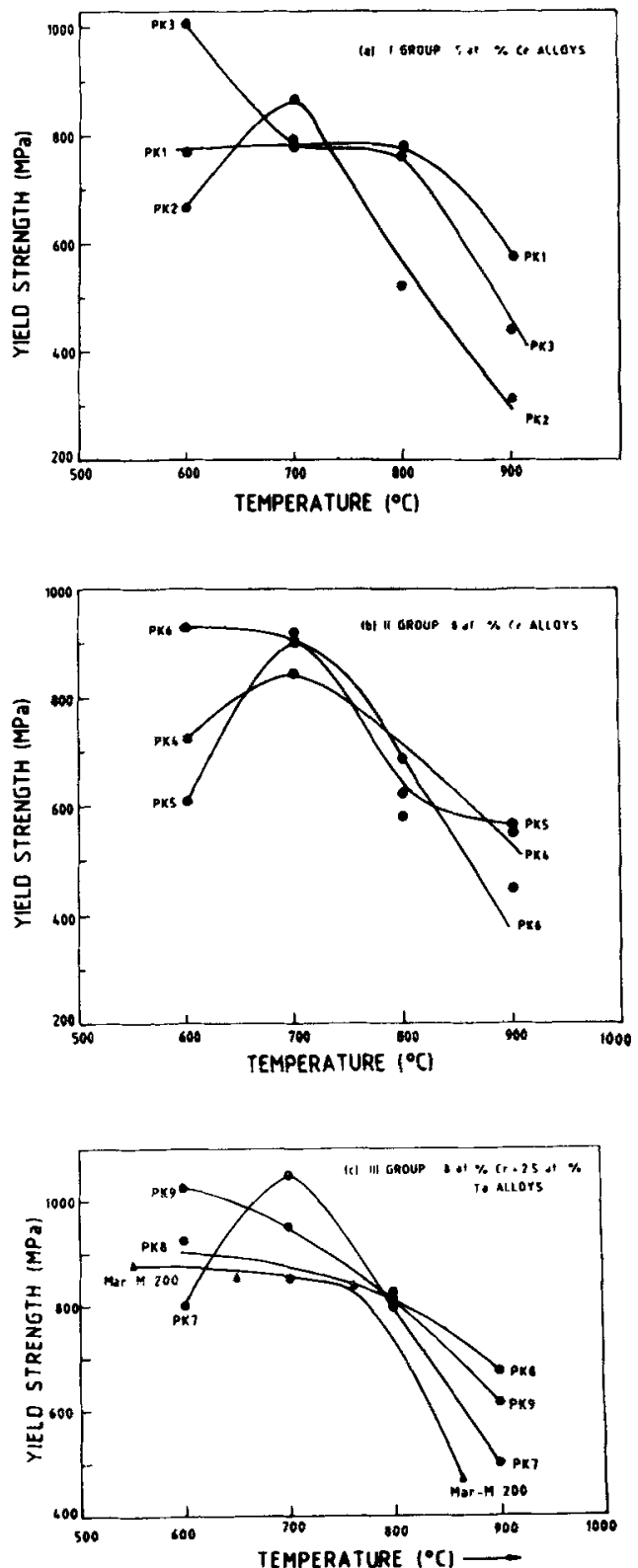

Figure 6. Hot compression test data for the button melted $\mathrm{Ni}_{3} \mathrm{Al}$-based alloys.

Table 3. Stress rupture data on as-DS PK8 alloy at $200 \mathrm{MPa}$.

\begin{tabular}{lccc}
\hline $\begin{array}{l}\text { Temperature } \\
\left({ }^{\circ} \mathrm{C}\right)\end{array}$ & $\begin{array}{c}\text { Rupture time } \\
(h)\end{array}$ & $\begin{array}{c}\text { Strain to } \\
\text { fracture } \\
(\%)\end{array}$ & $\begin{array}{c}\text { Reduction in } \\
\text { area at fracture } \\
(\%)\end{array}$ \\
\hline 900 & 266 & 3 & 6 \\
950 & 28 & 5 & 10 \\
\hline
\end{tabular}




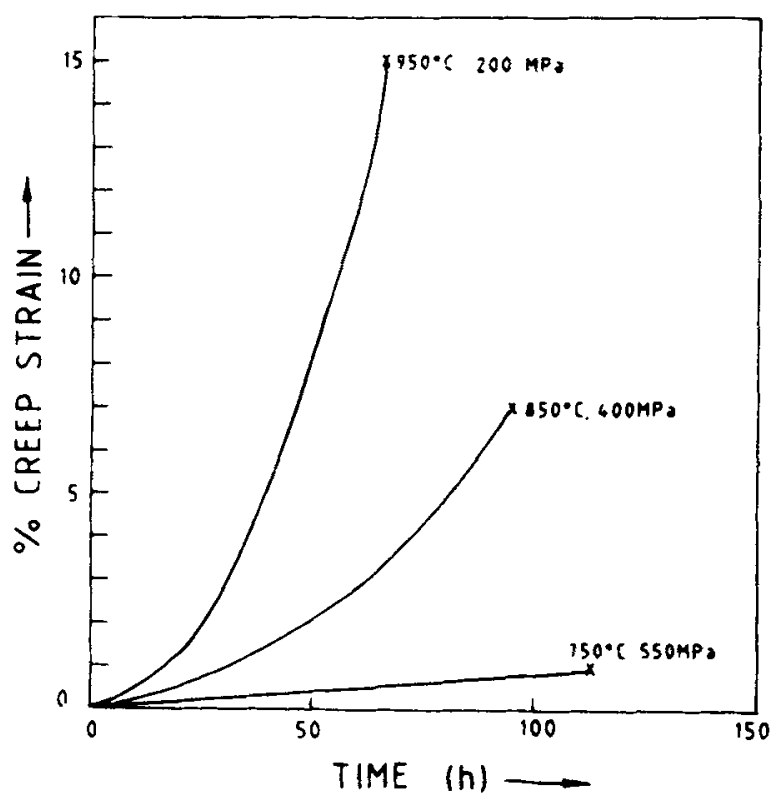

Figure 7. Creep curves for homogenized DS PK8 alloy.

Table 4. Effect of homogenization treatment on stress rupture properties of DS PK8 alloy tested at $900^{\circ} \mathrm{C}$ and $200 \mathrm{MPa}$.

\begin{tabular}{lccc}
\hline $\begin{array}{l}\text { Temperature } \\
\left({ }^{\circ} \mathrm{C}\right)\end{array}$ & $\begin{array}{c}\text { Rupture time } \\
(h)\end{array}$ & $\begin{array}{c}\text { Strain to } \\
\text { fracture } \\
(\%)\end{array}$ & $\begin{array}{c}\text { Reduction in } \\
\text { area at fracture } \\
(\%)\end{array}$ \\
\hline 1000 & 90 & 4 & 2 \\
1050 & 266 & 2 & 6 \\
1120 & 380 & 10 & 12 \\
1200 & 348 & 16 & 14 \\
\hline
\end{tabular}

Table 5. Creep properties of homogenized DS PK8 alloy.

\begin{tabular}{lccc}
\hline $\begin{array}{l}\text { Temperature } \\
\left({ }^{\circ} \mathrm{C}\right)\end{array}$ & $\begin{array}{c}\text { Stress } \\
(\mathrm{MPa})\end{array}$ & $\begin{array}{c}\text { Creep life } \\
(h)\end{array}$ & $\begin{array}{c}\text { Creep strain } \\
(\%)\end{array}$ \\
\hline 750 & 550 & 113 & 1 \\
850 & 400 & 95 & 8 \\
950 & 200 & 66 & 15 \\
\hline
\end{tabular}

structure are expected to have superior creep resistance than conventional nickelbased superalloys. However, a comparison of rupture life and creep rate between a DS $\mathrm{Ni}_{3} \mathrm{Al}$ based alloy (PK 8 alloy) and a DS Mar-M 200 demonstrates that the latter is not really the case. This finding is similar to that observed in $\mathrm{Ni}_{3}(\mathrm{Al}$, Ti) and $\mathrm{Mar}-\mathrm{M}$ 246 by Davies and Johnson (1970). 
Table 6. Comparison of minimum creep rate data of homogenized DS PK8 alloy with DS Mar-M 200.

\begin{tabular}{lccc}
\hline Alloy & $\begin{array}{c}\text { Temperature } \\
\left({ }^{\circ} \mathrm{C}\right)\end{array}$ & $\begin{array}{c}\text { Stress } \\
(\mathrm{MPa})\end{array}$ & $\begin{array}{c}\text { Minimum } \\
\text { creep rate } \\
\left(\times 10^{4} \mathrm{~h}\right)\end{array}$ \\
\hline DS PK8 & 750 & 550 & 0.2 \\
& 850 & 400 & $2 \cdot 75$ \\
DS Mar-M 200 & 950 & 200 & 4.6 \\
& 760 & 621 & 0.4 \\
& 982 & 207 & 4.5 \\
& 1082 & 69 & 1.3 \\
\hline
\end{tabular}

In conventional nickel-based superalloys, $\mathrm{Ni}(\tau) / \mathrm{Ni}_{3} \mathrm{Al}\left(\tau^{\prime}\right)$ interface restricts the motion of dislocations in addition to solid solution strengthened nickel matrix. In $\mathrm{Ni}_{3} \mathrm{Al}$-based alloys, there is no such interface which can impede dislocation motion. These observations suggest that at high temperature, if no strain hardening mechanism is available, YS consideration alone can lead to misleading expectations with respect to long term creep resistance as revealed from the present creep studies on PK8 alloy.

\section{Conclusions}

(i) Of the nine $\mathrm{Ni}_{3} \mathrm{Al}$-based alloys chosen, PK8 alloy showed YS superior to $\mathrm{CC}$ Mar-M 200 at all the chosen test temperatures in the hot compression studies.

(ii) As-DS PK8 alloy showed very low rupture life and ductility at 900 and $950^{\circ} \mathrm{C}$. Vacuum homogenization treatment for $20 \mathrm{~h}$ at various temperatures resulted in marked improvements both in terms of rupture life and ductility. Optimum stress rupture properties resulted from $1120^{\circ} \mathrm{C}, 20 \mathrm{~h}$ treatment.

(iii) Homogenized DS PK8 alloy showed relatively higher creep rate even at lower temperatures and stress levels as compared to the data available for DS Mar-M 200 from gas turbine application considerations.

\section{References}

Aoki K and Izumi O 1979 Nippon Kinzoku Gakkaishi 431190

Davies R G and Johnson T L 1970 Proc. of 3rd Bolton Landing Conf. on Ordered alloys-structural applications and physical metallurgy (eds) B H Kear, C T Sims, N H Stoloff and J H Westbrook, (Baton Rouge, Louisiana, USA: Claitor's Publishing Division) p. 447

Liu C T, Jemian W, Cathcart J V, David S A, Horton J A and Santella M L 1984 Report No. ORNL-6067, Oak Ridge National Laboratory, USA

Mishima Y, Ochiai S and Suzuki T 1985 Acta Metall. 331161

Mishima Y, Ochiai S, Hamao N, Yodogawa M and Suzuki S 1986 Trans. Jpn. Inst. Met. 27656

Ochiai S, Oya Y and Suzuki T 1984a Acta Metall. 32289

Ochiai S, Mishima Y and Suzuki T 1984b Bull. P.M.E. (T.I. T.) 5315

Paidar V, Pope D P and Vitek V 1984 Acta Metall. 32435

Piearcey B J and Terkelsen B E 1967 Trans. AIME 2391143

Pope D P and Ezz S S 1984 Int. Metall. Rev. 29136

Skinner E N and Talbot A M 1949 ASM Trans. 41136

Superalloys II 1987 Materials for aerospace and industrial power, (eds) C T Sims, N S Stoloff and W C Hagel (New York: John Wiley \& Sons) chap. 4

Takasugi T, Izumi O and Masahashi N 1985 Acta Metall. 331259 